\title{
Mobile Payment Service and the Firm Value: Focusing on both Up- and Down-Stream Alliance
}

\author{
Insung Son ${ }^{1}$ (i) and Sihyun Kim ${ }^{2, *}$ (1) \\ 1 Department of Management, Gyeongsang National University, Jinjudae-ro 501, JinJu 52828, Korea; \\ insung_son@gnu.ac.kr \\ 2 Department of Logistics, Korea Maritime and Ocean University, Busan 49112, Korea \\ * Correspondence: sihyunkim@kmou.ac.kr
}

Received: 20 June 2018; Accepted: 13 July 2018; Published: 23 July 2018

\begin{abstract}
The Fintech business, which was initially focused on the payment sector, is becoming a global issue due to the entry of nonfinancial firms into the banking business. With the advent of the "mobile age in your hand", global ICT companies are actively entering the banking business through alliances and competitions with existing financial companies. Classifying the alliance companies of Apple Pay and Samsung Pay into the downstream alliance and the upstream alliance, this study analyzed the signaling effect of service opening and its impact on the firm value. To analyze the effect of a specific event on firm value, this study adopted the event study. Additionally, ordinary least squares regression analysis was carried out to examine the influence of up- and downstream alliance on the firm value. The result shows that Apple Pay's service launch in the USA. has a positive impact on stock prices of up- and downstream alliance companies, providing new experience and satisfaction to users through active alliance with credit card companies. On the other hand, downstream alliance companies that showed a negative response to the launch of Korean services turned to a positive response to USA service launch because to the difference in the specificity of credit card penetration rate and the portion of premium smartphones. Analyzing the impact of the expansion of the service area toward the payment platform on the firm value, research results provide important implications for establishing technology management strategies to ensure the sustainability in rapidly changing technical advances by comparing the different market response of Apple Pay and Samsung Pay.
\end{abstract}

Keywords: Fintech; mobile payment service; Apple Pay; Samsung Pay; strategic alliance

\section{Introduction}

Fintech is a payment system that combines information technology and finance. In recent years, digitization, which is the core of the fourth industrial revolution such as blockchain, big-data, AI, and IoT, is accelerating, opening the "mobile age in your hand". According to 2017 "Fintech Rankings Top 100" presented by the IDC (International data corporation), countries such as the USA, UK, Japan, and China are investing heavily in the Fintech business. The Fintech business, which was initially focused on the payment sector, is becoming a global issue due to the entry of nonfinancial firms into the banking business and is expanding its area into financial data analysis, financial software, and payment platform. Especially global ICT companies such as Apple, Google, Samsung, Amazon, Alibaba, and eBay are actively entering the banking business through alliance and competition with existing financial companies.

Recently, Apple and Samsung have launched a new payment service applying technology related to mobile payment, providing a new user experience. Through the active alliance with credit card companies, banks and distributors from a mid- to long-term perspective, Apple Pay is attracting continuous customer loyalty in the already built ecosystem. Apple Pay is also providing new value 
and creating new revenue sources in a changing consumer culture by linking a service platform called iCloud, Wallet's product platform which enables real payment in iPhone and technical platform which provides NFC and Touch ID. On the other hand, Samsung Pay allowed users to use existing magnetic cards with no extra cost by applying the MST method which does not support Apple Pay in the payment function of smartphone. It implements the strong security performance with fingerprint authentication, payment token, and KONX.

In the mobile payment service market, Apple has been playing only a key role in the value chain and has partnerships with the most competitive companies by function for the remaining sectors. It launched the Apple Pay service to maintain competitive advantage through mutually complementary value creation with a horizontal relationship in a competitive position within the same industry, not a vertical value chain relationship such as buyer and supplier. Such an attempt to incorporate credit card functions into the smartphone as a means of payment has shifted from the convergence led by mobile operators to the convergence by smartphone manufacturers. In nature, this convergence is a phenomenon closer to technology-driven rather than market-driven. It is applied to all areas of existing financial services such as payment, fund brokerage, risk management, information management, etc., advancing the innovation of the financial industry. This innovation can be found in technologies such as near field communication (NFC) and magnetic secure transmission (MST) capabilities of leading mobile companies including Apple and Samsung. In fact, Apple Pay and Samsung Pay service is a model in which smart phones emulate and replace existing credit cards and is a variation of the payment method that users have already used. This service has the attribute of innovation that supplements the infrastructure of the existing banking business and directly supplies financial services to change the value chain.

To provide these services, Apple and Samsung have established an alliance with various companies in the value chain and broadened their service area toward the payment platform. Despite high attention to strategic cooperation related to a new payment service, prior studies are insufficient and the focus was mainly on technical issues rather than an alliance relationship for carrying out a new payment service.

This study aimed to classify the companies that participated in Apple Pay and Samsung Pay in terms of value chain into hardware-centered downstream alliance and service-centered upstream alliance, and to analyze the signal impact of the alliance on the firm's value. Therefore, we divided the alliance companies of Apple Pay and Samsung Pay into downstream alliance and upstream alliance and compared the signaling effect of mobile payment service launch and expansion of the service area towards payment platform on the firm value in different markets including USA and Korea. After introducing research background, we conceptualize the research model and review the relevant literature in Section 2. Research methodology including sample design and research methods adopted is discussed in the Section 3. The results of hypotheses tests are presented and discussed in Section 4. The results show that Apple Pay's service has a positive impact on stock prices of upstream and downstream alliance companies. On the other hand, Samsung featuring downstream alliance showed a negative response to Samsung Pay's service launch in Korea. In the case of Samsung Pay USA service, the software-centered upstream alliance companies were found to have a high innovation capacity and adequate slack resources, increasing the short-term firm value. This study revealed that the different market responses are caused by the effect of the specificity of credit card penetration rate in the market and the portion of premium smartphones. Comparing the differences in the differential market response of downstream alliance and upstream alliance of Apple Pay and Samsung Pay provides important implications for the technological management strategy establishment of companies to be sustainable in rapidly changing technical advances. 


\section{Literature Review and Hypothesis Development}

\subsection{Mobile Payment Service}

As users' behavior changes from the existing PC-based to the mobile-based one, prior studies related to the mobile payment service are carried out [1,2]. Mobile payment service means that payment or billing in the purchase of a product or service is processed by a mobile terminal with the advantages of wireless communication and other communication technologies [3]. In the past, the payment system used credit card or PC-based online remittance. Recently, the increase in smartphone users has also affected people's lifestyle and service usage, and mobile-based payment methods are rapidly changing. Recently, mobile payment service is used as online service and offline service depending on usage. An online service is to pay for products purchased on smartphone online, such as AliPay and Paypal. An offline service is a payment made by a mobile device when purchasing a product at a real shop, such as Apple Pay and Samsung Pay.

Apple Pay is a mobile payment service based on NFC and convenient and stable because it provides services through the token method of exchanging virtual codes with the Touch ID of iPhone 6. Specifically, Apple does not provide direct payment services, but it manages several issuers, acquirers, and payment systems that perform this function as a token service provider (TSP). From the start, Apple has focused on spreading Apple Pay by involving many complementary operators through a strategic alliance. For example, Apple is expanding its value chain through the alliance with credit card companies such as AMEX, MasterCard and Visa, and retail outlets such as BOA, Citi, Chase, and McDonald's. On the other hand, Samsung Pay with an excellent hardware base uses a MST-based technology to adopt a platform in which the magnetic field inside the smartphone is tokenized, enabling the payment without direct contact with the card terminal. Samsung does not receive any commission fees to secure the Fintech market, which can be interpreted as the purpose of Fintech's market dominance by spreading terminals rather than conflicts with affiliates due to the commission issue.

As mentioned above, the key to mobile payment services lies in user convenience, security and service infrastructure. In terms of payment procedure, Samsung Pay uses the method of contacting the payment terminal after user authentication, and Apple Pay uses the authentication method when contacting the payment terminal. It can be said that Samsung Pay and Apple Pay show strength in the compatibility and convenience of payment, respectively.

\subsection{Platform and Down.Upstream Alliance}

The change in the smartphone industry, triggered by the launch of the iPhone in 2007, has shifted from vertical relationships to horizontal relationships between platform operators such as Apple and mobile carriers, and competition to gain a competitive advantage is intensified. In this process, iPhone based on closeness and the OS platform of the Android aiming at openness are competing, and new types of platforms such as mobile payment services are gradually emerged [4].

Apple is building a platform that combines operating system (iOS) $\leftrightarrow$ service (App Store) $\leftrightarrow$ product (iPhone) vertically, as shown in Figure 1. This Apple-centered ecosystem is limited to iPhone-based services, and Apple is in charge of development tools to app registration examination, so the initiative has shifted from mobile carriers to Apple. As shown in Figure 1, Apple has built a closed platform ecosystem, but chose the open R\&D strategy, an open technology innovation for the active acceptance of external technology in the development process of iPhone [4]. Google, which declared the opening of terminal manufacturers and market platforms, is showing the suddenly increasing dominance in the Android-centered open ecosystem. In this environment, Samsung, a terminal maker, is able to release new products without restriction by installing a continuously upgraded Android OS. It is possible to make competitive innovation through competition between enterprises through open-centered-ecosystem, and consumers can choose various terminals in a competitive environment. In other words, Android users can choose from a wider variety of terminals than iPhone users who rely only on Apple's innovation and experience the progress of technological innovation accordingly. 


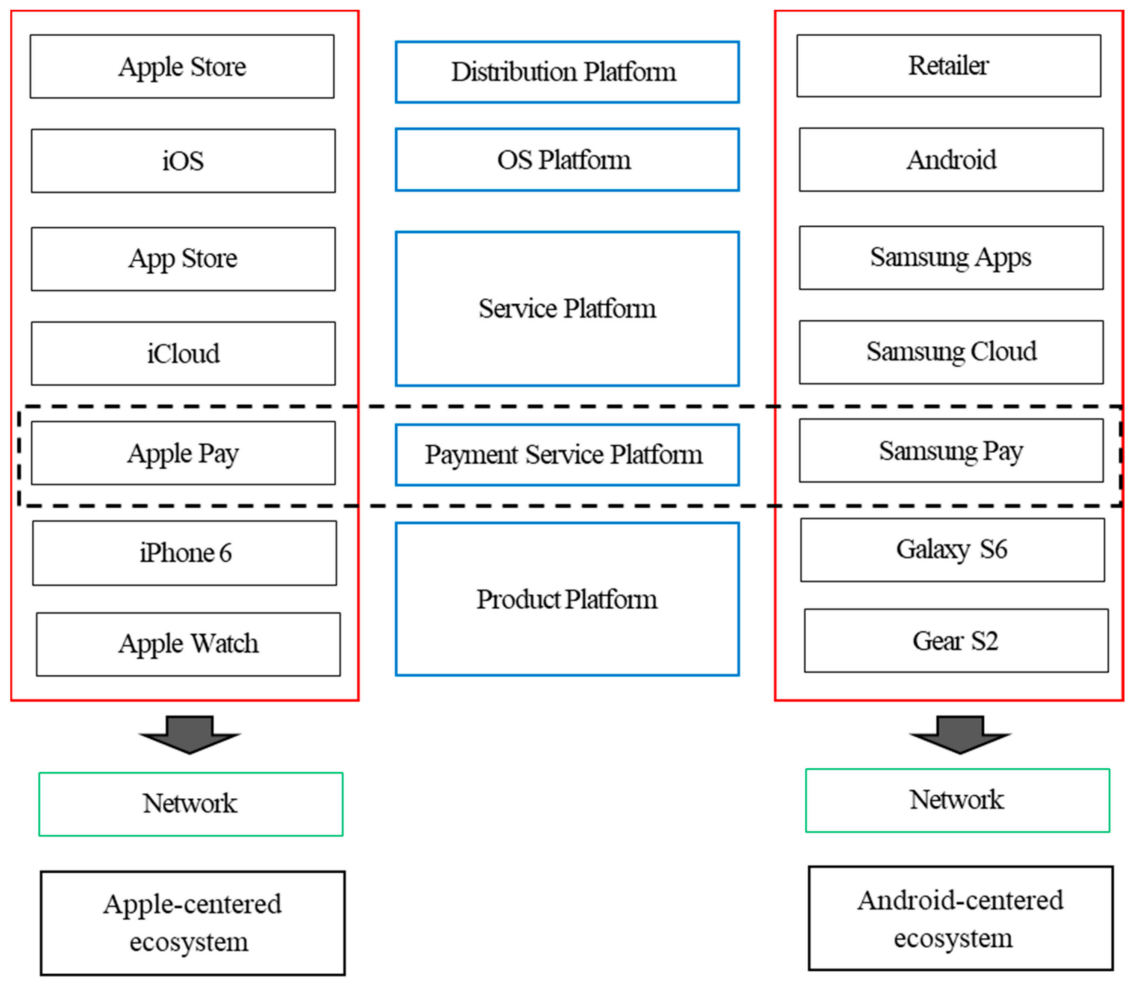

Figure 1. Platform paradigm of the smartphone industry.

From a platform perspective, Apple has strong control by building its own ecosystem connecting product platforms, service platforms, payment platforms, and distribution platforms, as shown in Figure 1, and maintains economies of scale and high loyalty of existing customers by using it. In other words, Apple is choosing to diversify and upgrade its services to increase consumer conversion costs as a starter [5].

As a latecomer, Samsung has chosen an open strategy to establish a virtuous cycle structure of network effects and platforms. However, despite its investment in various platforms such as OS platform (Bada), music platform (MILK) and messenger platform (ChatON), there are no successful cases yet. On the other hand, the recent trend in mobile payment platform can be found in the Apple Pay service, which tries to strengthen the control over the users already secured, and the Samsung Pay service, which tries to expand the inflow route of new users through openness. Recognizing the essence of mobile ecosystem as a platform building, Apple and Samsung are developing and introducing a payment service platform, and expanding its influence to the payment related value chain. We think that the settlement platform that they have established will have a performance lock-in effect outside the network, so that both the supplier and the user will stick to a specific provider and a competitive structure favorable to starters will be formed.

Table 1 summarizes the studies on downstream alliance and upstream alliance in the value chain. Using the number and the ratio of downstream and upstream alliances from an organizational learning theory and resource-based theory perspective, most of them classify manufacturing and marketing into downstream alliance and R\&D into upstream alliance.

Recently, there has been a study on service platforms that include both the market role and the participant role according to the value chain [6]. Especially, the way in which value is created in service platform ecosystem shows various types distinguished from traditional manufacturing. First, the value flow of simple forms such as social commerce is linear, sequential, and added value is accumulated sequentially according to traditional value chains. On the other hand, the payment service platform with the non-linear value creation process shows a complex parallel flow where 
various entities participate because the transaction is ongoing while the platform at the point of contact with the customer coordinates processes such as requests from the payment agency and approval of banks or financial institutions. As shown above, the payment service provider with value chain type is dominating the cost reduction and standardization by connecting the upstream and downstream participants and providing services according to the linear value flow.

Table 1. Previous studies on upstream alliance and downstream alliance.

\begin{tabular}{|c|c|}
\hline Researcher & Specific Details \\
\hline \multirow{4}{*}{ Park et al. [7] } & Theory: Resource based; Strategic behavior; domain: function; focus: Prior study \\
\hline & Empirical analysis: Number of upstream and downstream alliances in the value chain \\
\hline & Sample: 1979-1989, 471 divisions, 171 U.S. semiconductor startup companies \\
\hline & $\begin{array}{l}\text { Conclusion: Companies with sufficient resources are more active in a volatility market and } \\
\text { companies with insufficient resources in a stable market }\end{array}$ \\
\hline \multirow{4}{*}{$\begin{array}{l}\text { Rothaermel and } \\
\text { Deeds [8] }\end{array}$} & Theory: Organizational learning, resource based; domain: function; focus: inference \\
\hline & Empirical analysis: Number of upstream/downstream alliances in the value chain \\
\hline & Sample: $1973-1997,2565$ alliances by 323 bio companies \\
\hline & Conclusion: Integration of Product Development by Exploratory Alliance \\
\hline \multirow{4}{*}{$\begin{array}{l}\text { Hoang and } \\
\text { Rothaermel [9] }\end{array}$} & Theory: Organizational learning; domain: function; focus: inference \\
\hline & Empirical analysis: Percentage of upstream/downstream alliances in the value chain \\
\hline & Sample: $1980-2000,412$ R\&D alliances promoted by large-scale pharmaceutical companies \\
\hline & $\begin{array}{l}\text { Conclusion: While the exploratory alliance experience is negative, utilization alliance } \\
\text { experience has the alliance network effect through past partners under the uncertainty of } \\
\text { the market for companies that are positive for R\&D performance }\end{array}$ \\
\hline \multirow{4}{*}{ Kauppila [10] } & Theory: Ambidextrous alliance; domain: function; focus: inference \\
\hline & Empirical analysis: Examples of upstream/downstream alliance activities of value chain \\
\hline & Sample: In-depth field survey of Finnish SMEs \\
\hline & $\begin{array}{l}\text { Conclusion: Ambidextrous organization allows companies to have exploration and } \\
\text { utilization partnerships }\end{array}$ \\
\hline \multirow{4}{*}{ Yang et al. [11] } & Theory: Resource based; domain: function; focus: inference \\
\hline & Empirical analysis: Number of upstream/downstream alliances in the value chain \\
\hline & $\begin{array}{l}\text { Sample: 1984-2006, } 753 \text { alliances between large USA pharmaceutical companies and small } \\
\text { and medium-sized bio companies }\end{array}$ \\
\hline & $\begin{array}{l}\text { Conclusion: Claims that the utilization alliance by SMEs increases the value of large } \\
\text { corporations more than exploratory alliances of large companies with high risk }\end{array}$ \\
\hline \multirow{4}{*}{$\begin{array}{l}\text { Ranganathan and } \\
\text { Rosenkopf [12] }\end{array}$} & Theory: Organizational learning; domain: function; focus: inference \\
\hline & Empirical analysis: Number of upstream/downstream alliances in the value chain \\
\hline & Sample: Technical standards of the PC industry, Knowledge network of R\&D alliances \\
\hline & Conclusion: Upstream; R\&D downstream: Manufacturing, marketing, licensing \\
\hline
\end{tabular}

Next, product-based payment services such as Apple Pay and Samsung Pay services are expanding their value chain offline by expanding their influence while attracting various participants in complementary relationships by actively accepting Fintech. The scalability of this value chain is expanding market dominance through Fintech innovation, which is the convergence of online and offline and influencing all stakeholders participating in the ecosystem (component suppliers, VAN-PG operators, banks, credit card companies, telecommunications companies, distributors, etc.).

In terms of the users, Williams [13] argued that fundamental aspects of E-commerce include making and receiving payments with users feeling secure when doing so, and ensuring the site is enjoyable and easy to use. Kazan et al. [14] analyzed the market response, the case of UK mobile payment platforms. They emphasized that mobile payment platforms could be delineated based on integrative or integratable on their value creation architecture, and direct, indirect, or open access on 
their value delivery architecture. In addition, Yu et al. [15] explored the development of China's mobile payment from the resource-based platform strategies. Gao et al. [16] analyzed Users' Continuous Usage Intention of QR Code Mobile Payment Services in China. However, there is no prior study on the comparison of the different market. Therefore, to compare the market response in the different market including USA and Korea, the impact of the signaling effect of mobile payment service launch and expansion of the service area towards payment platform on the firm value. In this study, we divide the stakeholders of Apple Pay and Samsung Pay into down and upstream alliances in the value chain and set the following hypotheses.

Hypothesis 1. The launch of Apple Pay service will have a positive impact on the firm value of downstream and upstream alliance companies in the value chain.

Hypothesis 2. The launch of Samsung Pay service will have a positive impact on the firm value of downstream and upstream alliance companies in the value chain.

\section{Methodology}

\subsection{Sample Design}

Stock price data required for company research in the value chain of Apple Pay and Samsung Pay services were collected in the following way. Based on Apple and Samsung's annual reports, we created a list of supplier suppliers, VAN-PG operators, carriers, and distributors in the value chain and collected the stock price data of USA and Korean companies from OSIRIS DB and KIS-Value, respectively, and classified events by the following criteria, and the details are as follows: First, the modified stock price was used as the daily closing price to maintain the stock price continuity. Second, the Apple Pay service was launched in the United States on 20 October 2014, and the event dates were adjusted for each country based on the start date. Third, the Samsung Pay service was launched in Korea and U.S.A. on 20 August 2015 and 28 September 2015, respectively, and the event dates were adjusted for each country based on the start date. Fourth, if the event date was not a stock trading day, it was excluded from the sample. Fifth, if the interval of each event period was less than six months, it was excluded from the sample.

For the event date, Apple Pay and Samsung Pay service start dates were classified by country. Table 2 shows the results of dividing companies participating in Apple Pay and Samsung Pay services into downstream alliance and upstream alliance.

Apple Pay was classified in the value chain as components (88), NFC (11), VAN-PG providers (8), carriers (3), credit card-banks (8) and retailers (27). In addition, Samsung Pay was selected and classified as components (80), NFC-MST (8), VAN-PG providers (19), fingerprint recognition companies (13), carriers (3), communication device companies (7), and internet software providers (6).

Apple Pay, which is trying to integrate credit cards and mobile phones, chooses a market-leading strategy to develop new products based on visible demand rather than technology-driven in which technology innovation precedes demand for products. Apple has adopted the Apple Pay service as the primary payment tool for existing App Store and iTunes subscribers for the purpose of enhancing the iOS ecosystem.

Apple Pay service has linked most card companies in the USA to about 500 financial institutions such as Amex, Visa, and MasterCard to ensure versatility, and provides financial services by engaging various stakeholders such as securing more than 200,000 large offline franchises (McDonald's, Nike, etc.). 
Table 2. Apple Pay and Samsung Pay's down and upstream alliance.

\begin{tabular}{cccccc}
\hline Division & \multicolumn{2}{c}{ Apple Pay } & \multicolumn{3}{c}{ Samsung Pay } \\
\hline Service Day & 20 October 2014 & & & 20 August 2015 & 28 September 2015 \\
\hline Model & iPhone 6 & USA & Galaxy S6 & Korea & USA \\
\hline \multirow{2}{*}{ Downstream alliance } & COMPONENT & 88 & COMPONENT & 80 & 80 \\
& NFC & 11 & NFC, MST & 8 & 8 \\
\hline & CERTIFICATION & 8 & PG & 9 & 6 \\
& BANKS & 5 & SECURITY & 7 & 8 \\
& CREDIT & 3 & VAN & 10 & 3 \\
\multirow{2}{*}{ Upstream alliance } & CARRIERS & 3 & Touch ID & 13 & 13 \\
& PLATFORM & 3 & ISS & 6 & 3 \\
& RETAILERS & 27 & CD & 7 & 3 \\
& & & CARRIERS & 3 & 131 \\
\hline
\end{tabular}

On the other hand, Samsung tried to enter the platform business through a lot of investment in OS development and services such as Milk music, ChatON, etc. to maintain and expand market share in smartphone market, which have not affected the market share increase yet. Thus, it takes a strategy to maintain and expand market share through Samsung Pay service which can enter the credit card market where the existing infrastructure is fully equipped based on unrivaled technology.

The Samsung Pay service enables payment at PG affiliated franchises through a strategic alliance with a payment gateway (PG) company. In addition, offline card payment can be made at payment franchises, and interpersonal remittances are also linked to the Samsung account through affiliation and are handling remittances between holders. In addition, Samsung is pursuing its business in partnership with credit card companies and financial service providers (PG-VAN providers) that have secured existing franchises to promptly enter the market in consideration of the complicated regulations in Korea. In addition, the company is pursuing a lock-in strategy through the combination of terminals and services rather than expanding profits from entering the payment market with no payment related fees policy.

\subsection{Measures and Data Analysis}

\subsubsection{Event Study}

In this study, we divided companies that have partnerships with Apple Pay and Samsung Pay services under the value chain in the mobile payment service market into hardware-centered downstream alliance and software-centered upstream alliance and conducted a case study based on service start date to identify differentiated market responses according to group characteristics. Event study methodology is an empirical method analyzing the effect of a specific event on firm value [17]. It is an appropriate method to extract the effect of a specific event of an individual company on the overall stock market fluctuation. An important aspect of event study method is to set an event day, estimate excess return and set a period.

To estimate and test excess return, this study implemented event study using market model. First, the estimation period to estimate excess return was based on daily stock price data from Day -170 to Day -6 and the regression coefficient $(\hat{\alpha}, \hat{\beta})$ of individual company stock $i$ was estimated according to OLS in Equation (1). Event day was set as the period from Day -5 to Day +5 . During this period, change in abnormal return was investigated. The five-day pre-event period was excluded from the estimation to rule out the effect of mobile payment service launching from individual stock price estimation [18]. It is likely that, if event day is accurate and there is no previous information leakage, stock market response on a specific event is observed on Days -1 and 0 [19].

$$
\mathrm{R}_{\mathrm{i}, \mathrm{t}}=\alpha_{\mathrm{i}}+\beta_{\mathrm{i}} \mathrm{R}_{\mathrm{m}, \mathrm{t}}+\varepsilon_{\mathrm{i}, \mathrm{t}}
$$


where $R_{i, t}$ represents individual company i's return on day $t ; R_{m, t}$ is the market portfolio return on day $\mathrm{t} ; \alpha_{\mathrm{i}}$ is he unique risk of individual company $\mathrm{i} ; \beta_{\mathrm{i}} \mathrm{R}_{\mathrm{m}, \mathrm{t}}$ is the change in individual company i's return according to change in the whole market; and $\varepsilon_{i, t}$ is the individual company i's error term on day $t$, explaining change in a specific firm's return that cannot explain market-wide change. It is assumed as $\mathrm{i} \cdot \mathrm{i} \cdot \mathrm{d} \cdot \mathrm{N}\left(0, \sigma_{\mathrm{i}}^{2}\right)$. Market portfolio return $\mathrm{R}_{\mathrm{m}, \mathrm{t}}$ employed here is the corresponding stock exchange's composite stock price index. The parameter of Equation (1) was estimated using regression analysis. Then, individual company i's excess return at the point $\mathrm{t}$ is calculated as follows:

$$
\begin{gathered}
\mathrm{AR}_{\mathrm{i}, \mathrm{t}}=\mathrm{R}_{\mathrm{i}, \mathrm{t}}-\hat{\alpha}_{\mathrm{i}}-\hat{\beta}_{\mathrm{i}} \mathrm{R}_{\mathrm{m}, \mathrm{t}} \\
\mathrm{AAR}_{\mathrm{t}}=\frac{1}{\mathrm{n}} \sum_{\mathrm{i}=1}^{\mathrm{N}} \mathrm{AR}_{\mathrm{i}, \mathrm{t}} \\
\mathrm{CAR}\left(\mathrm{t}_{1}, \mathrm{t}_{2}\right)=\sum_{\mathrm{t}=-5}^{5} \mathrm{AR}_{\mathrm{t}}
\end{gathered}
$$

where $A R_{i, t}$ is excess return of individual company $i$ on day t. $C A R\left(t_{1}, t_{2}\right)$ is the cumulative average excess return during the event period from $t_{1}$ to $t_{2}$ (CAR). The average excess return (AAR) means the average value of excess return calculated in each sample. The cumulative average excess return refers to the cumulative value of average excess return during the $(-5,5)$ period. This study employed the method of Brown and Warner [20] that assumes the independence of statistical significance of $\mathrm{CAR}\left(\mathrm{t}_{1}, \mathrm{t}_{2}\right)$ and $\mathrm{AAR}_{\mathrm{t}}$ during the derived event period as in Equation (5):

$$
\mathrm{t}_{\mathrm{AAR}}=\frac{\mathrm{AAR}_{\mathrm{t}}}{\operatorname{Var}\left(\mathrm{AAR}_{\mathrm{t}}\right)}, \mathrm{t}_{\mathrm{CAR}\left(\mathrm{t}_{1}, \mathrm{t}_{2}\right)}=\frac{\mathrm{CAR}\left(\mathrm{t}_{1}, \mathrm{t}_{2}\right)}{\operatorname{Var}\left(\mathrm{CAR}\left(\mathrm{t}_{1}, \mathrm{t}_{2}\right)\right)}
$$

The difference test to analyze the difference between cumulative average excess return between downstream alliance companies and upstream alliance companies was analyzed with Equation (6).

$$
\operatorname{CAR}\left(t_{1}, t_{2}\right)^{\prime} \text { s difference analysis : } t=\frac{\operatorname{CAR}\left(t_{1}, t_{1}\right)^{\text {DOWN }}-\operatorname{CAR}\left(t_{1}, t_{1}\right)^{\mathrm{UP}}}{\sqrt{\operatorname{var}\left(\operatorname{CAR}\left(t_{1}, t_{1}\right)\right)^{\mathrm{DOWN}}+\operatorname{var}\left(\operatorname{CAR}\left(\mathrm{t}_{1}, \mathrm{t}_{1}\right)\right)^{\mathrm{UP}}}}
$$

where $\operatorname{CAR}\left(t_{1}, t_{2}\right)^{\text {DOWN }}$ is cumulative average excess return from the event period $t_{1}$ to $t_{2}$ between downstream alliance partners and $\operatorname{CAR}\left(t_{1}, t_{2}\right)$ UP is cumulative average excess return from the event period $t_{1}$ to $t_{2}$ between upstream alliance partners.

\subsubsection{Panel Analysis}

This section examines which factors mainly explain the increment of firm value, due to up- and downstream alliance. For this purpose, we estimated and verified excess return using event studies to divide Apple and Samsung's partners to launch Apple Pay and Samsung Pay services, respectively, in the Fintech industry into hardware-centered downstream alliance and software-centered upstream alliance according to collective characteristics and identify discriminatory market responses. On the other hand, to analyze the impact of financial characteristic variables, innovation capacity and slack resources on excess return, companies were divided into upstream and downstream alliance companies and OLS (ordinary least squares) regression analysis was carried out. The models are as follows:

$$
\begin{aligned}
& \text { Model } 1: \text { AP_AR }{ }_{i, 0}=\beta_{1} \text { DU_DUMMY }+\beta_{2} \mathrm{IC}_{\mathrm{i}, \mathrm{t}-1}+\beta_{3} \mathrm{SLACK}_{\mathrm{i}, \mathrm{t}-1}+\beta_{4} \mathrm{SIZE}_{\mathrm{i}, \mathrm{t}-1}+\beta_{5} \mathrm{LEV}_{\mathrm{i}, \mathrm{t}-1}+\beta_{6} \mathrm{PPE}_{\mathrm{i}, \mathrm{t}-1}+\varepsilon_{\mathrm{i}} \\
& \text { Model } 2: \mathrm{SP} \_\mathrm{AR}_{\mathrm{i}, 0}=\beta_{1} \mathrm{DU} \_\mathrm{DUMMY}+\beta_{2} \mathrm{IC}_{\mathrm{i}, \mathrm{t}-1}+\beta_{3} \mathrm{SLACK}_{\mathrm{i}, \mathrm{t}-1}+\beta_{4} \mathrm{SIZE}_{\mathrm{i}, \mathrm{t}-1}+\beta_{5} \mathrm{LEV}_{\mathrm{i}, \mathrm{t}-1}+\beta_{6} \mathrm{PPE}_{\mathrm{i}, \mathrm{t}-1}+\varepsilon_{\mathrm{i}}
\end{aligned}
$$

where $A P \_A R_{i, 0}$ is the excess return of Apple Pay service start date $\left(t_{0}\right)$; $S P \_A R_{i, 0}$ is the excess return of Samsung Pay service start date $\left(\mathrm{t}_{0}\right)$; DU_DUMMY is a dummy variable with a value 
of 1 for downstream alliance and 0 for upstream alliance; $\mathrm{IC}_{\mathrm{i}, \mathrm{t}-1}$ is the innovation capacity, and an independent variable with $R \& D$ expenditure divided by total assets; $\mathrm{SLACK}_{\mathrm{i}, \mathrm{t}-1}$ is the slack resources, and an independent variable with retained earnings divided by total assets; SIZE $_{\mathrm{i}, t-1}$ is the company size, and a control variable with a logged value of total assets; $\mathrm{LEV}_{\mathrm{i}, \mathrm{t}-1}$ is the leverage ratio, and a control variable with total debt divided by total assets; and $\mathrm{PPE}_{\mathrm{i}, \mathrm{t}-1}$ is the tangible asset ratio, and a control variable with a value divided by total assets. In addition, the variables included in the analysis are standardized by dividing them by total assets to control the heterogeneity of the scale effect [21].

The dependent variables use the excess return $\left(\mathrm{AP}_{-} \mathrm{AR}_{\mathrm{i}, 0}\right)$ of Apple Pay service start date and the excess return (SP_AR $\left.R_{i, 0}\right)$ of Samsung Pay service start date. The independent variables use innovative capacity $\left(\mathrm{IC}_{\mathrm{i}, \mathrm{t}-1}\right)$ and slack $\left(\mathrm{SLACK}_{\mathrm{i}, \mathrm{t}-1}\right)$ variables, which are expected to affect the upstream and downstream partners in the start of mobile payment service. The independent variables use innovation capacity and slack resources. $R \& D$ concentration of dividing R\&D expenditure, the proxy of innovation capability by total assets is the most used in the previous research [22]. Therefore, this study uses R\&D expenditure as an index of innovation capacity. To control the heterogeneity of the scale effect due to differences in total assets, R\&D expenditure was divided by total assets. The measurement of slack resources uses retained earnings [23]. Dechow et al. [24] argued that retained earnings exceeding net profit during the term increase the firm's market value. Therefore, this study used retained earnings as an index of slack resources.

This study used firm size $\left(\mathrm{SIZE}_{\mathrm{i}, \mathrm{t}-1}\right)$, debt ratio $\left(\mathrm{LEV}_{\mathrm{i}, \mathrm{t}-1}\right)$, and tangible asset ratio $\left(\mathrm{PPE}_{\mathrm{i}, \mathrm{t}-1}\right)$ as control variables. The firm size uses the value obtained by taking the natural log of total assets, and the larger the partner company is, the better the performance in terms of the innovation and growth rate. Alliances with large companies acts as a high performance factor in smaller companies with less experience in related fields because their alliance companies with a high reputation has the effect of free ride. Low debt ratios may cause companies to lose opportunities for profit creation. Higher tangible asset ratio has a positive effect on the firm value. All independent variable and control variable uses the first lag of the book value of individual firms' accounting data at the fiscal year end, immediately launching to the date of mobile payment service.

\section{Results and Discussion}

\subsection{Signal Effect of Mobile Payment Service}

Table 3 shows the results of dividing the stock price response to the start of the Apple Pay service, which is the starting leader in the mobile payment service, into the downstream and upstream alliances under the value chain and showing average excess return (AAR). First, the AAR of the hardware-centered downstream alliance firms shows statistically significant results at the event day (Day 0 ) at the 1\% level, 1.94\%. The service-oriented upstream alliance companies such as credit card companies and banks are statistically significant at the $5 \%$ level, and the average excess return is $1.04 \%$, which is half of the downstream alliance companies. This result can be interpreted as, in the case of Apple Pay, hardware-centered downstream alliance company belonging to the iPhone's ecosystem, such as NFC, has a higher excess return than the service-centered upstream alliance.

Table 4 presents the results of the average excess return of the samples that divide the stock response of the Samsung Pay Korean service start into downstream and upstream alliances under the value chain. First, the AAR of the hardware-centered downstream alliance companies such as MST is $-3.47 \%$ at the event date (Day 0), which is statistically significant at the $5 \%$ level and shows a negative value, but the AAR of the service-centered upstream alliance companies is $2.07 \%$, which is statistically significant at the $5 \%$ level and shows a positive value $(+)$.

Table 5 indicates the results of dividing the share price response to Samsung Pay's USA service start into the downstream and upstream alliances under the value chain and shows the average excess return of the samples. The AAR of the companies participating in the downstream alliance is $0.77 \%$ at 
the event day (Day 0), which is significant and positive at $5 \%$ level. In addition, firms participating in the upstream alliance have a higher excess return than the downstream alliance firms with a significant AAR of $0.85 \%$ at the $5 \%$ level.

The clear difference between the Korean launch of Samsung Pay and its USA launch is that the Korean launch is negative in downstream alliance but it has turned into a positive outcome in the USA launch. These results can be explained by the positive response of the market to the explosion of users who have experienced the generality and convenience of Samsung Pay in a short period of time since its launch in Korea and the specificity of the USA credit card market.

Table 3. AAR and CAR down and upstream alliance companies of Apple Pay USA Services.

\begin{tabular}{ccccccccc}
\hline \multirow{2}{*}{ Day } & \multicolumn{3}{c}{ Downstream Alliance $(\boldsymbol{N}=\mathbf{9 9 )}$} & \multicolumn{3}{c}{ Upstream Alliance $(\boldsymbol{N}=\mathbf{4 9 )}$} \\
\cline { 2 - 9 } & AAR (\%) & t-Value & CAR (\%) & t-Value & AAR (\%) & t-Value & CAR (\%) & t-Value \\
\hline-5 & 0.71 & 1.06 & 0.71 & 1.06 & 0.41 & 0.94 & 0.41 & 0.94 \\
-4 & 0.61 & 0.92 & 1.32 & 1.40 & -0.16 & -0.37 & 0.24 & 0.40 \\
-3 & 1.13 & 1.70 & 2.45 & 2.12 & 0.23 & 0.53 & 0.47 & 0.63 \\
-2 & 0.15 & 0.23 & 2.60 & 1.95 & 0.28 & 0.64 & 0.75 & 0.87 \\
-1 & 0.65 & 0.98 & 3.26 & 2.18 & 0.73 & 1.69 & 1.48 & 1.53 \\
0 & 1.94 & $2.91 * * *$ & 5.20 & 3.18 & 1.04 & $2.40 * *$ & 2.53 & 2.38 \\
+1 & -0.58 & -0.88 & 4.61 & 2.61 & -0.35 & -0.81 & 2.18 & 1.89 \\
+2 & 0.60 & 0.90 & 5.21 & 2.76 & 0.55 & 1.26 & 2.72 & 2.22 \\
+3 & 0.82 & 1.23 & 6.03 & 3.02 & 0.23 & 0.53 & 2.95 & 2.27 \\
+4 & 0.11 & 0.17 & 6.14 & 2.91 & 0.03 & 0.07 & 2.98 & 2.17 \\
+5 & 0.86 & 1.30 & 7.01 & 3.17 & 0.56 & 1.30 & 3.55 & 2.46 \\
\hline \multicolumn{8}{c}{ Significance levels: ${ }^{* *} p<0.01 ;{ }^{* * *} p<0.001}$. &
\end{tabular}

Table 4. AAR and CAR down- and upstream alliance companies of Samsung Pay Korea Services.

\begin{tabular}{|c|c|c|c|c|c|c|c|c|}
\hline \multirow{2}{*}{ Day } & \multicolumn{4}{|c|}{ Downstream Alliance $(N=88)$} & \multicolumn{4}{|c|}{ Upstream Alliance $(N=55)$} \\
\hline & AAR $(\%)$ & t-Value & CAR (\%) & t-Value & AAR (\%) & t-Value & CAR (\%) & t-Value \\
\hline-5 & 1.94 & 1.31 & 1.94 & 1.31 & -0.34 & -0.41 & -0.34 & -0.41 \\
\hline-4 & -0.68 & -0.46 & 1.26 & 0.60 & 0.46 & 0.56 & 0.12 & 0.11 \\
\hline-3 & 0.05 & 0.03 & 1.31 & 0.51 & -0.75 & -0.92 & -0.63 & -0.44 \\
\hline-2 & -1.66 & -1.12 & -0.35 & -0.12 & -0.47 & -0.58 & -1.10 & -0.67 \\
\hline-1 & -0.85 & -0.58 & -1.21 & -0.36 & 0.24 & 0.29 & -0.86 & -0.47 \\
\hline 0 & -3.47 & $-2.35 * *$ & -4.67 & -1.29 & 2.07 & $2.53 * *$ & 1.21 & 0.60 \\
\hline+1 & 1.36 & 0.92 & -3.31 & -0.85 & -0.12 & -0.15 & 1.08 & 0.50 \\
\hline+2 & -0.14 & -0.10 & -3.45 & -0.83 & -0.49 & -0.60 & 0.59 & 0.26 \\
\hline+3 & -1.38 & -0.93 & -4.83 & -1.09 & 0.53 & 0.65 & 1.13 & 0.46 \\
\hline+4 & -0.93 & -0.63 & -5.76 & -1.23 & 0.69 & 0.84 & 1.81 & 0.70 \\
\hline+5 & -0.42 & -0.28 & -6.18 & -1.26 & -0.45 & -0.56 & 1.36 & 0.50 \\
\hline
\end{tabular}

Companies that have a downstream alliance with Samsung include parts suppliers of Galaxy S6 and Samsung Pay related module companies (NFC, MST, antennas, etc.), which are in a close vertical integration relationship with Samsung. Samsung Pay is expecting a positive market reaction because users can use the existing card directly with an MST payment method not supported by Apple Pay, but the opposite result is shown. The result of the negative reaction of Samsung Pay's launch of its service in Korea can be found in the case of failure of Samsung's existing platform launch. Specifically, Samsung has made no effort to build an ecosystem through active investment such as Bada on the OS platform, MILK on the music platform, and ChatON on the messenger platform, but there are no successful results. In other words, it can be explained that there is no existing success story, so investors have been reacting negatively to the launch of the Samsung Pay service, a payment platform as a latecomer. It can be interpreted that Apple, as a starter, can negotiate with its stakeholders (banks, credit card companies, retailers, etc.) on an equal footing with buyer-centered 
bargaining power within the already established ecosystem, but, in the case of Samsung, a latecomer, the supplier-centered weak bargaining power and the burden on MST, a time limit technology applied to Samsung Pay, act as negative effects. On the other hand, the positive effects of service-oriented companies (PG-VAN operators, credit card companies, banks, security companies, etc.) that have an upstream alliance with Samsung were found to be free ride effects based on Samsung's no-fee policy

Table 5. AAR and CAR down- and upstream alliance companies of Samsung Pay USA Services.

\begin{tabular}{ccccccccc}
\hline \multirow{2}{*}{ Day } & \multicolumn{3}{c}{ Downstream Alliance $(\boldsymbol{N}=\mathbf{8 8})$} & \multicolumn{3}{c}{ Upstream Alliance $(\boldsymbol{N}=\mathbf{4 3})$} \\
\cline { 2 - 8 } & AAR (\%) & t-Value & CAR $(\%)$ & t-Value & AAR (\%) & t-Value & CAR (\%) & t-Value \\
\hline-5 & -0.56 & -1.57 & -0.56 & -1.57 & 0.15 & 0.36 & 0.15 & 0.36 \\
-4 & -0.40 & -1.14 & -0.96 & -1.92 & 0.35 & 0.81 & 0.50 & 0.83 \\
-3 & 0.25 & 0.69 & -0.72 & -1.16 & 0.30 & 0.70 & 0.80 & 1.08 \\
-2 & -0.17 & -0.49 & -0.89 & -1.25 & -0.31 & -0.72 & 0.49 & 0.57 \\
-1 & 0.26 & 0.73 & -0.63 & -0.79 & -0.50 & -1.17 & -0.01 & -0.01 \\
0 & 0.77 & $2.16^{* *}$ & 0.14 & 0.16 & 0.85 & $1.98 * *$ & 0.84 & 0.80 \\
+1 & -0.04 & -0.12 & 0.09 & 0.10 & -0.13 & -0.30 & 0.71 & 0.63 \\
+2 & -0.44 & -1.24 & -0.35 & -0.34 & -0.02 & -0.05 & 0.69 & 0.57 \\
+3 & 0.27 & 0.76 & -0.08 & -0.07 & -0.41 & -0.95 & 0.28 & 0.22 \\
+4 & 0.49 & 1.39 & 0.42 & 0.37 & 0.16 & 0.37 & 0.44 & 0.33 \\
+5 & 0.21 & 0.59 & 0.63 & 0.53 & -0.10 & -0.24 & 0.34 & 0.24 \\
\hline \multicolumn{7}{c}{ Significance levels: ${ }^{* *} p<0.01}$. & &
\end{tabular}

First, as shown in Table 6, the magnetic card penetration rate $(92.7 \%)$ in the USA market is $\geq 12$ times the IC card penetration rate (7.3\%). Due to these factors, Samsung Pay service, which do not consider electronic settlement as a no-fee policy as a means of generating profits, is improving its utility by meeting the interests of various market participants in the existing offline payment market.

Next, premium smartphones accounted for $57.1 \%$ of the USA market, with Apple and Samsung occupying most of them, of which Android OS's market share is $33.6 \%$. Estimated shipments of premium models equipped with Android in 2015 are 183 million units, the USA market share is about 62 million units, and Samsung Pay's service launch in the U.S. can be interpreted as having high utility. On the other hand, in the Samsung Pay USA service launch, service-oriented upstream alliance firms have higher excess return than hardware-oriented downstream alliance firms such as MST, which can be interpreted that Samsung is still vulnerable to payment service-related parts, so active investment in this area is necessary.

Table 6. Regional penetration rate according to credit card usage.

\begin{tabular}{|c|c|c|c|c|c|}
\hline \multirow{2}{*}{$\begin{array}{c}\begin{array}{c}\text { Classification } \\
\text { (Unit: \%) }\end{array} \\
\text { Region }\end{array}$} & \multirow{2}{*}{$\begin{array}{c}2013 \\
\begin{array}{c}\text { Card Payment } \\
\text { Usage Rate }\end{array}\end{array}$} & \multicolumn{2}{|c|}{2014} & \multicolumn{2}{|c|}{2015} \\
\hline & & $\begin{array}{l}\text { Magnetic Card } \\
\text { Penetration Rate }\end{array}$ & $\begin{array}{l}\text { IC Chip Card } \\
\text { Penetration Rate }\end{array}$ & $\begin{array}{l}\text { Premium Model } \\
\text { Proportion }\end{array}$ & $\begin{array}{c}\text { Android } \\
\text { Market Share }\end{array}$ \\
\hline U.S.A & 43.7 & 92.7 & 7.3 & 57.1 & 33.6 \\
\hline $\begin{array}{l}\text { Western } \\
\text { Europe }\end{array}$ & 22.9 & 16.5 & 83.5 & 43.8 & 38.9 \\
\hline Asia & 19.5 & 74.6 & 25.4 & 23.9 & 44.6 \\
\hline $\begin{array}{c}\text { Central and } \\
\text { South America }\end{array}$ & 7.7 & 40.5 & 59.5 & 18.1 & 47.3 \\
\hline Eastern Europe & 3.2 & 59.6 & 40.4 & 29.4 & 65.8 \\
\hline $\begin{array}{c}\text { Middle } \\
\text { East/Africa }\end{array}$ & 2.7 & 49.5 & 50.5 & 19.3 & 74.8 \\
\hline
\end{tabular}

Data: International EMV (Europay, MasterCard, VISA), 2016. 


\subsection{Difference Analysis}

Table 7 presents the results of dividing group variables into upstream alliance and downstream alliance and analyzing difference for independent sample with the test variable as CAR to identify how the average cumulative excess return change depending on the collective nature of the companies involved in the launch of the Apple Pay and Samsung Pay services.

Table 7. Downstream alliance and upstream alliance CAR's difference analysis.

\begin{tabular}{cccccc}
\hline Payment Service & Period & Downstream Alliance & Upstream Alliance & Difference & t-Value \\
\hline $\begin{array}{c}\text { Apple Pay } \\
\text { (Launch in the U.S.A.) }\end{array}$ & CAR $(-5,5)$ & 4.05 & 1.84 & 2.21 & $7.78^{* * *}$ \\
\hline $\begin{array}{c}\text { Samsung Pay } \\
\text { (Launch in Korea) }\end{array}$ & CAR $(-5,5)$ & -2.29 & 0.39 & -2.69 & $-2.30^{* *}$ \\
\hline $\begin{array}{c}\text { Samsung Pay } \\
\text { (Launch in the U.S.A.) }\end{array}$ & CAR $(-5,5)$ & 2.27 & 2.23 & 0.43 & 1.35 \\
\hline \multicolumn{5}{c}{ Significance levels: ${ }^{* *} p<0.01 ;{ }^{* * *} p<0.001}$.
\end{tabular}

For the start of the Apple Pay service in the United States, the downstream alliance has a significantly higher excess return than the upstream alliance at $1 \%$ level more consistently. This can be interpreted that, in the case of Apple, hardware companies similar to technology alliances in the payment platform launch show a more positive response than software companies that are similar to market alliances. In Samsung Pay's service launch in Korea, the excess return of downstream alliance is significantly higher at $1 \%$ than the upstream alliance, which shows a positive response. This can be explained as Samsung is not a free rider in the launch of the payment platform, but, as a leading company, the investor's negative reaction to the application of the new technology has been projected.

The launch of the Samsung Pay service in the USA shows similar results for both the downstream and upstream alliances, indicating that it is not significant. This can be interpreted as a positive response of the market to the explosive increase in the number of users who have experienced Samsung Pay's versatile and convenient user interface during the period of USA service launch (28 September 2015) after the launch of Korean service (20 August 2015).

\subsection{Result of OLS Regression Analysis}

OLS regression analysis was conducted to analyze the impact of innovation capacity, slack resources, which are financial characteristic variables of upstream and downstream alliance companies of Apple Pay, Samsung Pay on the excess return. Table 8 presents the results of the regression analysis of the factors affecting the excess return by dividing the mobile payment service into the Apple Pay USA service, Samsung Pay Korea service, and Samsung Pay USA service. First, the DU_Dummy variable shows a significant positive coefficient $(0.017, t=2.73)$ at the $1 \%$ level in the Apple Pay USA service. This means that, for Apple Pay, product-driven downstream alliance companies have a positive impact on the excess return. Specifically, the innovation competency variable shows a significant positive coefficient $(0.038, t=2.92)$ at the $1 \%$ level. This means that hardware-centered downstream alliance firms have their innovation capabilities in the Apple Pay service, increasing their short-term firm value. Slack resources also show a significant positive coefficient $(0.035, t=2.47)$ at the $5 \%$ level. This means that hardware-centered downstream alliance firms have adequate slack resources in the Apple Pay service, increasing their short-term firm value.

In the Samsung Pay Korea service, the DU_Dummy variable shows an insignificant positive coefficient $(0.013, \mathrm{t}=1.56)$. This means that, in the case of Samsung Pay Korea services, the service-oriented upstream alliance companies have no impact on excess return. Specifically, the innovation capacity variable $(0.011, t=1.37)$ and slack resource variable $(0.013, t=1.52)$ show an insignificant positive coefficient value. This means that, in the case of software-centered upstream 
alliance firms, innovation capacity and slack resources have no impact on short-term firm value in the Samsung Pay Korea Service.

On the other hand, the DU_Dummy variable shows a significant positive coefficient $(0.023, t=2.53)$ at the $5 \%$ level in the Samsung Pay USA service. This means that, in the case of Samsung Pay USA service, service-centered upstream alliance firms have a positive impact on the excess return. Specifically, the innovation capacity variable $(0.027, t=2.42)$ and slack resource variable $(0.031, t=2.12)$ show significant positive coefficients $(0.038, t=2.92)$ at the $5 \%$ level. This means that, in the case of Samsung Pay USA service, software-centered upstream alliance firms have higher innovation capacity and adequate slack resources, increasing their short-term firm value.

Table 8. Regression analysis of excess return of mobile payment service start date.

\begin{tabular}{|c|c|c|c|}
\hline Variable & $\begin{array}{c}\text { Apple Pay } \\
\text { USA Service }\end{array}$ & $\begin{array}{l}\text { Samsung Pay } \\
\text { Korea Service }\end{array}$ & $\begin{array}{l}\text { Samsung Pay } \\
\text { USA Service }\end{array}$ \\
\hline DU_Dummy & $\begin{array}{c}0.017^{* * *} \\
(2.73)\end{array}$ & & \\
\hline DU_Dummy & & $\begin{array}{l}0.013 \\
(1.56)\end{array}$ & $\begin{array}{c}0.023 \text { ** } \\
(2.53)\end{array}$ \\
\hline IC & $\begin{array}{c}0.038^{* * *} \\
(2.92)\end{array}$ & $\begin{array}{c}0.011 \\
(1.37)\end{array}$ & $\begin{array}{c}0.017^{* *} \\
(2.42)\end{array}$ \\
\hline SLACK & $\begin{array}{c}0.035^{* *} \\
(2.47)\end{array}$ & $\begin{array}{l}0.013 \\
(1.52)\end{array}$ & $\begin{array}{c}0.031^{* *} \\
(2.12)\end{array}$ \\
\hline SIZE & $\begin{array}{c}0.019^{* * * *} \\
(2.62)\end{array}$ & $\begin{array}{c}0.021 * * \\
(2.14)\end{array}$ & $\begin{array}{c}0.026^{* * *} \\
(2.81)\end{array}$ \\
\hline LEV & $\begin{array}{l}0.016 \\
(1.31)\end{array}$ & $\begin{array}{l}0.009 \\
(1.15)\end{array}$ & $\begin{array}{l}0.024 \\
(1.43)\end{array}$ \\
\hline PPE & $\begin{array}{l}0.023 \\
(1.45)\end{array}$ & $\begin{array}{l}0.008 \\
(1.38)\end{array}$ & $\begin{array}{l}0.007 \\
(1.16)\end{array}$ \\
\hline $\mathrm{N}$ & 139 & 133 & 123 \\
\hline Adjusted_R ${ }^{2}$ & 0.23 & 0.22 & 0.21 \\
\hline F & $5.12^{* * *}$ & $5.08^{* * *}$ & $4.97^{* * *}$ \\
\hline
\end{tabular}

The results in Table 8 indicate that investors in the stock market regard Apple Pay services provided by Apple as a starter as a positive signal. That is, hardware-centered downstream alliance companies have a high level of innovation capacity and adequate slack resources, meaning that there is a high correlation with short-term firm value. These results are consistent with the argument that higher innovation capacity and appropriate slack resources lead to active investment, increasing firm value. Meanwhile, Samsung Pay service by Samsung as a latecomer is highly correlated with short-term firm value because software-centered upstream alliance companies have a higher innovation capacity and appropriate slack resources. These results mean that Samsung Pay served by Samsung as a latecomer is highly correlated with short-term firm value because software-centered upstream alliance companies have a higher innovation capacity and appropriate slack resources. In other words, it can be interpreted that Samsung is more vulnerable to the software sector than Apple, so active investment in this area is required.

\section{Conclusions}

In rapidly changing technical advances, firms need to adopt new technologies to be sustainable [25]. Apple and Samsung have launched a new payment service applying technology 
related to mobile payment, providing a new user experience. This study divided the alliance formed between Apple and Samsung to enter the mobile payment service market into the upstream and downstream alliances in the value chain, and analyzed its impact on firm value.

The results provide the following implications: Firstly, it was found that Apple Pay's service launch in the U.S. has a positive impact on stock prices of upstream and downstream alliance companies. This means that Apple draws the continuous loyalty of existing customers by enhancing convenience and security based on the users secured in the ecosystem they have already built. It can be interpreted as a successful seating was possible because Apple with buyer-centered bargaining power has provided new experience and satisfaction to users through active alliance with credit card companies with payment networks and banks and distributers that issue cards.

Secondly, hardware-centered downstream alliance companies in a close vertical integration relationship with Samsung showed a negative response to Samsung Pay's service launch in Korea. These results can be attributed to the market reaction to the failure of Samsung's existing platform launch (Bada), the supplier-centered bargaining power (free fee) as a latecomer, and the time limit of MST technology applied to Samsung Pay (three years).

Thirdly, Samsung Pay's service launch in the USA showed a clear difference in downstream alliance companies compared to Korean service launch. In other words, downstream alliance companies that showed a negative response to the launch of Korean services turned to a positive response to American service launch. The difference between these responses is caused by the effect of Samsung Pay depending on the specificity of credit card penetration rate in the USA market and the portion of premium smartphones.

Lastly, it was found that, in the case of software-centered upstream alliance firms in Samsung Pay Korean services, innovation capacity and slack resources have no impact on short-term firm value. On the other hand, in the case of Samsung Pay USA service, the software-centered upstream alliance companies were found to have a high innovation capacity and adequate slack resources, increasing the short-term firm value. These results mean that Samsung Pay served by Samsung as a latecomer is highly correlated with short-term firm value because software-centered upstream alliance companies have a higher innovation capacity and appropriate slack resources. In other words, it can be interpreted that Samsung is more vulnerable to the software sector than Apple, so active investment in this area is required.

In addition, this study revealed the difference between the first mover and the fast follower in the beginning of the mobile payment service through empirical analysis from the viewpoint of the value chain of Apple Pay and Samsung Pay that launched their service in the mobile payment service market and analyzed the market response of these companies. This study is of significance in that it identified the reason the downstream alliance companies which have a negative reaction to the start of the Korean service turned into a positive response to American service launch in the country-specific comparison of Samsung Pay service. The results of this study analyzed the impact on market participants based on the beginning of payment services of buyer bargaining power-centered Apple and supplier bargaining power-centered Samsung in downstream alliance and upstream alliance to present a new empirical view on the study of the value chain. Lastly, because this study is based on cross-sectional data, it does not tap any macro-economic change, which would require a longitudinal approach. The robustness of future studies would be enhanced by utilizing market and/or macro-economic variables from each organization over time. In addition, future research involving the value chain of a variety of payment methods is required such as eBay's PayPal and Alibaba's Alipay, which are large-scale distributors that preempt customers with the core rights of the payment process in the online field.

Author Contributions: I.S. developed the original idea for the study. I.S. were responsible for data collection. S.K. conducted the data analyses. All the authors contributed to drafting the manuscript and approved the final version of the manuscript.

Funding: This research received no external funding.

Conflicts of Interest: The authors declare no conflict of interest. 


\section{References}

1. Schierz, P.G.; Schilke, O.; Wirtz, B.W. Understanding consumer acceptance of mobile payment services: An empirical analysis. Electron. Commer. Res. Appl. 2010, 9, 209-216. [CrossRef]

2. Slade, E.; Williams, M.; Dwivedi, Y.; Piercy, N. Exploring consumer adoption of proximity mobile payments. J. Strat. Mark. 2015, 23, 209-223. [CrossRef]

3. Dahlberg, T.; Mallat, N.; Ondrus, J.; Zmijewska, A. Past, present and future of mobile payments research: A literature review. Electron. Commer. Res. Appl. 2008, 7, 165-181. [CrossRef]

4. Thomas, R.E.; Parker, G.; Alstyne, M.V. Opening Platforms: How, When and Why? Working Paper; Harvard Business School: Boston, MA, USA, 16 October 2008.

5. Cho, Y.H.; Lee, G.G. A study on the impact factors of open innovation performance according to the first-mover companies and the follower companies. J. Inf. Technol. Appl. Manag. 2013, 20, 40-56.

6. Huang, B.; Li, C.; Yin, C.; Zhao, X. Cloud manufacturing service platform for small-and medium-sized enterprises. Int. J. Adv. Manuf. Technol. 2013, 65, 1261-1272. [CrossRef]

7. Park, S.H.; Chen, R.; Gallagher, S. Firm resources as moderators of the relationship between market growth and strategic alliances in semiconductor start-ups. Acad. Manag. J. 2002, 45, 527-545.

8. Rothaermel, F.T.; Deeds, D.L. Exploration and exploitation alliance in biotechnology: A system of new product development. Strat. Manag. J. 2004, 25, 201-221. [CrossRef]

9. Hoang, H.; Rothaermel, F.T. Leveraging internal and external experience: Exploration, exploitation, and R\&D project performance. Strat. Manag. J. 2010, 31, 734-758.

10. Kauppila, O.P. Creating ambidexterity by integrating and balancing structurally separate interorganizational partnerships. Strat. Organ. 2010, 8, 283-312. [CrossRef]

11. Yang, H.; Zheng, Y.; Zhao, X. Exploration or exploitation? Small firms' alliance strategies with large firms. Strat. Manag. J. 2014, 35, 146-157. [CrossRef]

12. Ranganathan, R.; Rosenkopf, L. Do ties really bind? The effect of knowledge and commercialization networks on opposition to standards. Acad. Manag. J. 2014, 57, 515-540. [CrossRef]

13. Kazan, E.; Tan, C.W.; Lim, E.T.K.; Sorensen, C.; Damsgaard, J. Disentangling digital platform competition: The case of UK mobile payment platforms. J. Manag. Inf. Syst. 2018, 35, 180-219. [CrossRef]

14. Yu, J.; Hu, W.; Zhang, Y. Exploring the development of China's mobile payment from the perspective of resource-based platform strategies. In Digital Enablement: The Consumerizational and Transformational Effects of Digital Technology; Pan, S.I., Sandeep, M.S., Eds.; World Scientific Publishing Co. Pte. Ltd.: Singapore, 2018; Chapter 11; pp. 179-198.

15. Gao, S.; Yang, X.; Guo, H.; Jing, J. An Empirical Study on Users' Continuous Usage Intention of QR Code Mobile Payment Services in China. Int. J. E-Adopt. 2018, 10, 18-33. [CrossRef]

16. Williams, M.D. Social commerce and the mobile platform: Payment and security perceptions of potential users. Comput. Hum. Behav. 2018. [CrossRef]

17. Son, I.; Kim, S. Does Partner Volatility Have Firm Value Relevance? An Empirical Analysis of Part Suppliers. Sustainability 2018, 10, 736. [CrossRef]

18. MacKinlay, A.C. Event studies in economics and finance. J. Econ. Lit. 1997, 35, 13-39.

19. Hendricks, K.B.; Singhal, V.R. Delays in new product introductions and the market value of the firm: The consequences of being late to the market. Manag. Sci. 1997, 43, 422-436. [CrossRef]

20. Brown, S.J.; Warner, J.B. Measuring security price performance. J. Financ. Econ. 1980, 8, 205-258. [CrossRef]

21. Lev, B.; Sougiannis, T. The capitalization, amortization, and value-relevance of R\&D. J. Account. Econ. 1996, 21, 107-138.

22. Lavie, D.; Rosenkopf, L. Balancing exploration and exploitation in alliance formation. Acad. Manag. J. 2006, 49, 797-818. [CrossRef]

23. Tseng, C.H.; Tansuhaj, P.; Hallagan, W.; McCullough, J. Effects of firm resources and growth in multinationality. J. Int. Bus. Stud. 2007, 38, 961-974. [CrossRef] 
24. Dechow, P.M.; Hutton, A.P.; Sloan, R.G. An empirical assessment of the residual income valuation model. J. Account. Econ. 1999, 26, 1-34. [CrossRef]

25. Kang, D.; Kim, S. Conceptual Model Development of Sustainability Practices: The Case of Port Operations for Collaboration and Governance. Sustainability 2017, 9, 2333. [CrossRef] 